\title{
PEMBUATAN BIOETANOL BERBAHAN BAKU KULIT SINGKONG DAN KULIT NANAS DENGAN VARIASI MASSA RAGI
}

\author{
Rachmat Subagyo'), Imam Ahdy Saga') \\ 1,2Program Studi Teknik Mesin \\ Fakultas Teknik Universitas Lambung Mangkurat ${ }^{12)}$ \\ JL. Akhmad Yani Km. 36 Banjarbaru, Kalimantan Selatan, 70714 \\ Telp. 0511-4772646, Fax 0511-477264 \\ E-mail : sagaimam24@gmail.com
}

\begin{abstract}
This study aims to determine the best bioethanol levels from a combination of cassava and pineapple peels mixture with variations of yeast mass as much as 11 grams, 13 grams, 15 grams and 72 hours fermentation time, to determine the optimal yeast mass and determine ethanol levels according to SNI. This research was carried out by hydrolysis using distilled water for 30 minutes, then fermentation using yeast and distillation process, then tested with a Refractometer Pen. Selected samples will be tested for ethanol content using the Gas Chromatography tool. The highest ethanol content of ethanol making with a combination of cassava and pineapple peels is for a combination of $75 \%$ cassava peel - $25 \%$ pineapple peel $88.6 \%$ in a 15 gram yeast mass, a combination of $50 \%$ cassava peel $-50 \%$ pineapple peel $89.3 \%$ in 15 gram yeast mass. So it can be concluded that the ethanol content of the combination of cassava and pineapple peels is not included in the category of Indonesian national standards (SNI).
\end{abstract}

Keywords : Cassava Peel, Pineapple Peel, Hydrolysis, Fermentation, and Destilation.

\section{PENDAHULUAN}

Sumber daya alam (Unrenewable resources) semakin menipis disebabkan sumberdaya alam ini tidak dapat diperbaharui. Konsumsi energi terus mengalami peningkatan, dengan bertambahnya penduduk dan laju perekonomian sebagai penyebab masalah ini. Salah satu contoh energi tak terbarukan adalah energi fosil yang merupakan energi utama saat ini di dunia.

Pemanasan global yang teradi di bumi diakibatkan oleh pemakaian bahan bakar fosil, dan dampaknya tehadap lingkungan semakin terasa. Hal inilah yang mendorong dikembangkannya bahan bakar alternative bersifa terbarukan. Alasan pencemaran lingkungan yang terjadi akibat pembakaran bahan bakar fosil berdampak pada kesehatan bagi manusia, hewan, bahkan tumbuhan.

Maka dari itu, saat ini upaya untuk menggali dan mengembangkan energi alternatif terus ditingkatkan. Salah satu energi yang termasuk energi terbaru yang harus bisa terus di kembangkan yaitu energy biomassa. Energi biomassa tersebut berasal dari bahan organik dan juga memiliki keragaman jenis. Energi biomassa dapat di buat dari tanaman seperti pada lahan perkebunan, pertanian, hutan, bahkan limbah, baik limbah domestik dan limbah pertanian. Biomassa ini tentunya tidak akan mengakibatkan penumpukan gas $\mathrm{CO}_{2}$, karena gas $\mathrm{CO}_{2}$ yang dihasilkan oleh reaksi pembakaran dipakai untuk pembentukan biomassa itu sendiri. Hasil konversi biomassa tersebut dapat berupa biogas, bioethanol, bioiesel, arang dan sebagainya. Tentunya dalam hal ini bioetanol dalam jangka panjang di harapkan dapat digunakan sebagai pengganti bahan bakar yang marak digunakan saat ini yaitu minyak.

Kulit nanas dan kulit singkong adalah limbah yang dapat berpotensi untuk dijadikan energi alternatif sebagai bioetanol. Pada kulit nanas terdapat kandungan 
karbohidrat dan gula yang cukup tinggi dan juga bahan yang mengandung karbohidrat terdapat pula pada limbah dari singkong yaitu pada kulit singkong.

Uraian diatas bertujuan untuk menjelaskan bahwa kulit nanas dan kulit singkong yang tentunya sebagai bahan baku baru pembuatan bioetanol sebagai bahan bakar alternatif, karena banyaknya industri di Indonesia yang menyisakan limbah tersebut. Disamping itu kulit nanas dan kulit singkong memiliki kandungan karbohidarat dan glukosa yang cukup tinggi. Sehingga dilakukan penelitian untuk mengetahui kadar bioetanol dari limbah tersebut.

Bioetanol adalah etanol bahan utama dari tumbuhan dan pada umumnya menggunakan proses fermentasi. Ethanol atau juga disebut ethyl alcohol $\mathrm{C}_{2} \mathrm{H}_{5} \mathrm{OH}$ merupakan cairan bening tak berwarna, terurai secara biologis (biodegradable), mengandung toksisitas rendah dan tidak menimbulkan polusi udara yang besar bila terjadi bocor. Ketela pohon adalah umbi- umbian yang mempunyai kandungan gizi yang diantaranya karbohidrat $36,8 \%$, lemak $0,3 \%$, serat $0,9 \%$, abu $0,5 \%$, dan air $61,4 \%$ (Zulaikah, 2002).

Bioetanol merupakan cairan biokimia proses fermentasi gula dari sumber karbohidrat menggunakan bantuan. Bioetanol diproduksi umumnya berasal dari etanol generasi pertama, yaitu etanol yang awalnya dibuat dari gula (tebu, molases) atau pati-patian (jagung, singkong, dII). Bahan-bahan tersebut merupakan bahan pangan (Bambang Prastowo, 2007).

Kulit nanas merupakan bagian luar dari buah nanas yang setiap kali berada di tangan konsumen selalu akan menjadi limbah dan terbuang. Hal tersebut berdampak pada lingkungan yang tidak enak dipandang dan bahkan dari segi bau limbah tersebut sangat mengganggu. Dengan adanya limbah kulit nanas itu haruslah diikuti dengan upaya penanganan dan pengolahan limbah yang baik. Kulit buah nanas diketahui cukup banyak mengandung gula, sehingga bias digunakan sebagai bahan baku dalam pembuatan bioetanol.

Kulit singkong merupakan limbah kupasan hasil pengolahan kripik, tapioca, tape, dan pangan berbahan dasar singkong lainnya. Kulit singkong mengandung karbohidrat yang cukup tinggi (Rukmana, 1997). Kulit singkong memungkan sumber karbohidrat yang berpotensial untuk diolah menjadi bioetanol.

Hidrolisis adalah reaksi kimia memecah molekul menjadi dua bagian dengan menambah molekul air $\left(\mathrm{H}_{2} \mathrm{O}\right)$, dengan tujuan mengkonversi polisakarida menjadi monomer-monomer sederhana. Satu bagian molekul memiliki ion hidrogen $\left(\mathrm{H}_{+}\right)$ dan bagian yang lain memiliki ion hidroksil $(\mathrm{OH})$. Hidrolisis terjadi saat garam dari asam lemah atau basa lemah (keduanya) terlarut dalam air. Adapun proses dilanjutkan ke tahap fermentasi.

Pengertian dari fermentasi selama ini berubah - ubah. Kata fermentasi berasal dari bahasa latin "fervere" yang artinya merebus (to boil). Arti kata dari bahasa latin itu bisa disamakan dengan kondisi cairan bergelembung dan mendidih. Keadaan ini timbulkan dengan adanya aktivitas ragi pada ekstraksi buah - buahan maupun biji - bijian (Suprihatin, 2010). Ragi mengubah gula menjadi etanol dan karbondioksida sesuai dengan rumus di bawah ini :

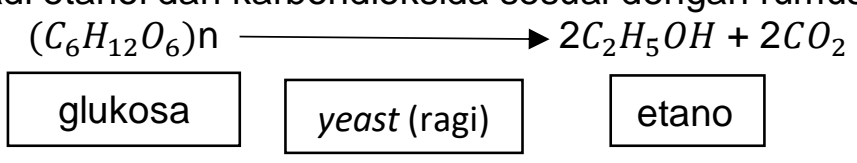

(Nurdyastuti, 2007)

Beberapa faktor yang mempengaruhi dalam proses fermentasi ragi adalah sebagai berikut : 
a. Lama Fermentasi (waktu)

Lama waktu yang dibutuhkan pada proses fermentasi adalah sekitar 2 - 3

hari (Astawan dan Mita, 1991)

b. Jenis Bahan (Substrat)

Fermenteasi dapat terjadi karena adanya aktifitas mikroba penyebab fermentasi pada substrat organic yang sesuai. Terjadinya fermentasi ini menyebabkan perubahan sifat pangan, sebagai akiat dari pemecahan kandungan bahan pangan tersebut. Hasil - hasil fermentasi terutama tergatung pada jenis bahan pangan (substrat), jenis mikroba dan kondisi lingkungannya yang mempengaruhi pertumbuhan dan metabolisme mikroba tersebut (Winarno, 1995).

c. Keasaman $(\mathrm{pH})$

Dalam fermentasi alkohol, ragi berpengaruh pada media dengan kondisi asam, antara $\mathrm{pH} 4,8-5,0$. Pengaturan $\mathrm{pH}$ bisa dengan penambahan asam sulfat jika substrat basa ataupun natrium bikarbonat jika substrat asam.

d. Suhu

Suhu optimal untuk petumbuhan dan perkembangannya adalah $28^{\circ} \mathrm{C}-30^{\circ} \mathrm{C}$.

e. Udara

Proses fermentasi alkohol berlangsung secara anaerobic, namun udara diperlukan pada proses pembibitan tersebut, sebelum fermentasi untuk perkembangbiakan ragi (Amien, 2006).

Dalam tahapan pembuatan bioethanol juga tidak lepas dari tahap destilasi. Destilasi merupakan proses penguapan dan pengembunan kembali, yang dimaksut untuk memisah campuran dua atau lebih zat cair kedalam fraksi fraksinya berdasarkan perbedaan titik didih. Umumnya, pemisahan hasil fermentasi glukosa atau dektrosa menggunakan system uap cairaan. Terdiri dari komponen tertentu yang mudah sekali tercampur. Destilasi berlangsung pada tekanan atmosfer, contohnya alkohol - air, yang pada tekanan atmosfer memiliki titik didih sebesar $78,6^{\circ} \mathrm{C}$. (Tjokroadikoesoemo, 1986)

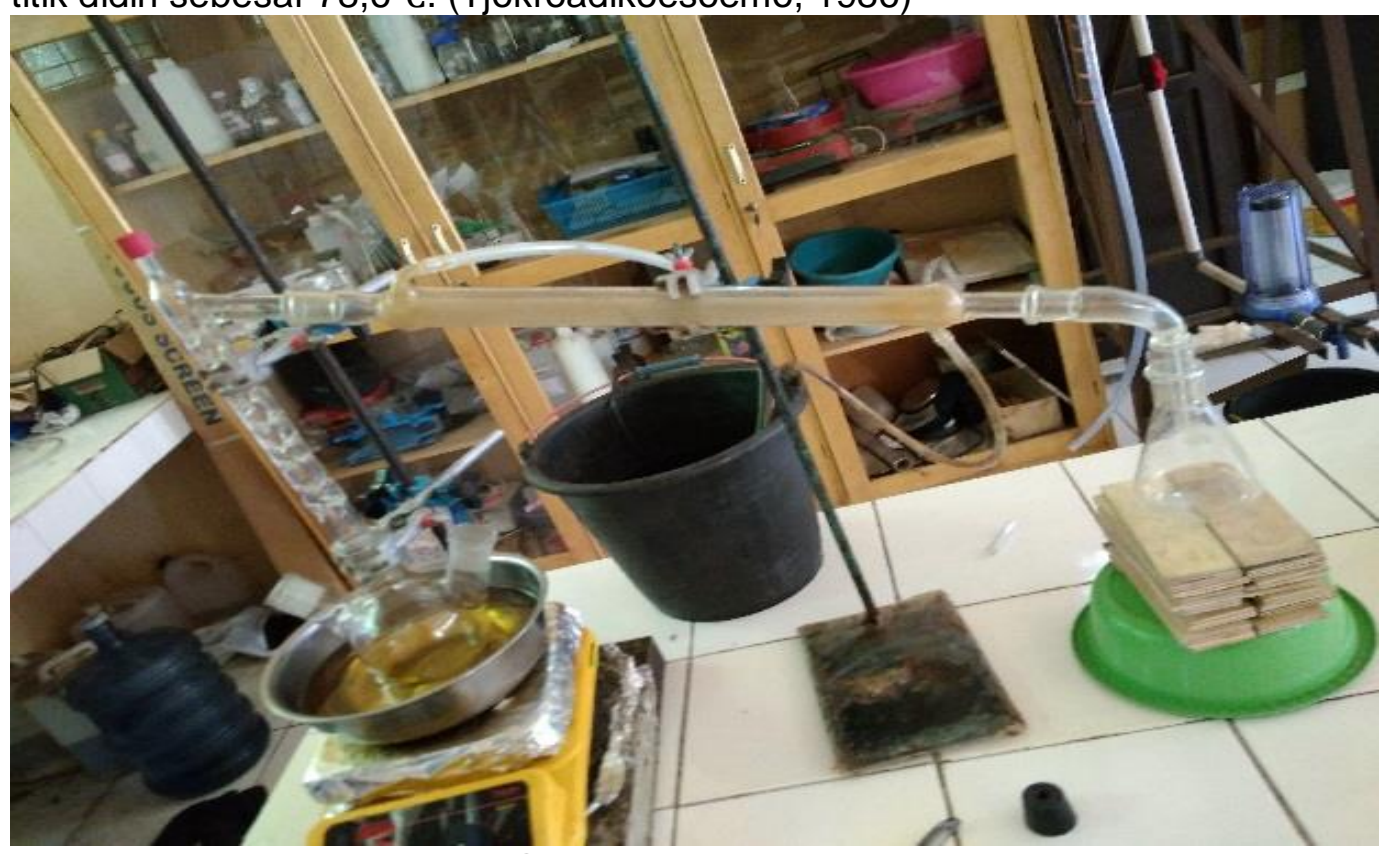

Gambar 1. Alat Destilasi

Kadar etanol menurut Badan Standarisasi Nasional Indonesia adalah 94,0\%. Pada penelitian ini kadar etanol yang didapat kemudian dihitung nilai randemennya. 
Randemen adalah perbandingan jumlah (kuantitas) etanol yang dihasilkan dari proses destilasi. Adapun rumus untuk menghitung randemen adalah sebagai berikut:

Randemen $(\%)=\frac{\text { jumlah ethanol yang dihasilkan }(\text { gram })}{\text { jumlah bahan sebelum diolah }} \times 100 \%$

Volume $($ gram $)=$ volume bahan $x$ density bahan

Hasil perhitungan randemen (table 1).

\section{KAJIAN LITERATUR DAN PENGEMBANGAN HIPOTESIS}

Ani Rahmawati (2010). Melakukan penelitian dengan judul "Pemanfaatan Limbah Kulit Ubi Kayu (Manihot Utilissima Pohl.) dan Kulit Nanas (Ananas Comosus L.) Pada Produksi Bioetanol Dengan Menggunakan Aspergillus Niger". Pada penelitian tersebut produk etanol campuran limbah kulit ubi kayu (Mannihot utilissima pohl.) dan limbah kulit nanas (Ananas comosus, L.) yaitu sebesar $7 \mathrm{ml}$ dengan kadar etanol $2,57 \%$, lebih banyak daripada hasil etanol pada masing masing limbah kulit ubi kayu dan limbah kulit nanas.

Sally Mardari,dkk (2013). Melakukan penelitian degan judul "Pembuatan Bioetanol berbahankan Kulit Nanas (ananas comusus I) Menggunakan Enzim Selulase dan Yeast Saccharomyces Cerevisiae dengan Proses Simultaneous Sacharification dan Fermentasion (SSF)". Pada penelitian tersebut waktu fermantasi penelitian diperoleh waktu fermentasi dengan kadar alkohol tertinggi yang dihasilkan yaitu 3 hari dikarenakan waktu terbaik Saccharomyces Cerevisiae bekerja mengubah glukosa menjadi bioethanol yaitu 3 hari.

Emma Khairani (2014). Melakukan penelitian dengan judul "Pemanfaatan Kulit Nanas Jadi Bioetanol" Pada penelitian tersebut dilakukan eksperimen dengan rancangan dengan perlakuan hingga didapat substrat sari kulit nanas yang siap proses menjadi bioetanol melalui proses fermentasi. Substrat ditambah Saacharomyces cereviceae pada bermacam perubah dan lanjutkan proses fermentasi. Hasil proses fermentasi dianalisis kadar glukosa sisa dan kadar bioetanolnya dengan GC. Sari kulit nanas dianalisis daripada kadar glukosanya, kemudian di tambah air dengan perbaningan (1:2) dan disterilisasi. Proses fermentasi dikerjakan pada suhu $25-30{ }^{\circ} \mathrm{C}, \mathrm{pH} 4-5$, dan ditambah urea. Selanjutnya proses distilasi pada suhu $78^{\circ} \mathrm{C}$, dan dianalisis kadar bioethanol yang diperoleh.

Dony Fahmi, dkk (2014). Melakukan penelitian dengan juduk "Pemurnian Etanol Hasil Fermentasi Kulit Nanas (Ananas comosus L. Merr) Dengan Menggunakan Distilasi Vakum". Pada penelitian tersebut nilai rendemen tertinggi diperoleh pada penelitian pemurnian etanol hasil proses fermentasi kulit nanas dengan menggunakan distilasi vakum adalah $1,166 \%$, semakin tinggi suhu distilasi yang digunakan, maka cairan yang teruapkan pada saat proses distilasi vakum berlangsung juga akan banyak sehingga akan semakin banyak pula uap yang dihasilkan yang selanjutnya akan terkondensasi menjadi etanol destilat didalam wadah penampung.

\section{METODE PENELITIAN}

\subsection{Tempat dan Waktu Penelitian}

Penelitian dilakukan di Workshop Teknik Kimia Universitas Lambung Mangkurat dan Laboratorium Energi LPPM Institut Teknologi Sepuluh Nopember pada bulan Maret 2018 sampai dengan Juni 2018.

\subsection{Alat dan Bahan Penelitian}

Adapun alat dan bahan yang digunakan dalam penelitian ini adalah sebagai berikut : botol, balon, blender, oven, kompor, destilator, gelas ukur, 
saringan, timbangan digital, termo Gun, botol sampel, pen refractometer, gas chromatography.

Bahan yang di gunakan dalam penelitian ini adalah limbah kulit singkong dan kulit nanas yang merupakan bahan baku utama pembuatan bioetanol. Dalam penelitian ini yang digunakan adalah kulit dari limbah usaha pasar Banjarbaru, Provinsi Kalimantan Selatan.

\subsection{Teknik Pengumpulan Data}

Kulit nanas dan kulit singkong yang sudah dikumpulkan dicuci hingga bersih, kemudian dijemur di bawah sinar matahari. Hasil pengeringan kemudian dihaluskan dengan blender hingga diperoleh tepung kulit nanas dan kulit singkong.

Ditimbang masing - masing bahan tepung kulit singkong dan kulit nanas sesuai dengan kombinasi campuran perbandingan berat bahan. Kemudian tepung kulit singkong dan kulit nanas di campur dengan air aquades $800 \mathrm{ml}$. Campuran di rebus selama 30 menit dengan suhu $100^{\circ} \mathrm{C}$ sambil di aduk.

Siapkan botol yang akan digunakan sebagai tempat fermentasi. Hasil hidrolisis di dinginkan dan di saring hingga tidak ada ampas dalam larutan hidrolisis. Campurkan ragi sesuai variasi sebanyak $11 \mathrm{gr}, 13 \mathrm{gr}$, dan $15 \mathrm{gr}$.

Tutup mulut botol menggunakan balon. Biarkan proses fermentasi berjalan dengan lama waktu fermentasi selama 72 jam.

Siapkan alat dan bahan, kemudian menyalakan pemanas alat destilasi. Tunggu hingga beberapa saat hingga suhu yang diinginkan telah dicapai. Dalam proses pada destilasi ini, suhu yang digunakan adalah $85^{\circ} \mathrm{C}$. Suhu dipertahankan sesuai lama proses destilasi. Lama proses untuk satu perlakuan adalah 2 jam. Sesudah sampel didapatkan, kemudian sampel ditampung dalam gelas ukur untuk diuji kadar etanolnya.

Bioetanol hasil proses destilasi diuji dengan alat Pen Refractometer di Laboratorium Operasi Teknik Kimia Fakultas Teknik Universitas Lambung Mangkurat untuk mengetahui ada atau tidaknya etanol yang terkandung dalam sampel hasil destilasi, dan kemudian akan dilakukan pengujian di Laboratorium Energi LPPM Institut Teknologi Sepuluh Nopember menggunakan Gas Chromatography guna mengetahui kadar bioetanol terbaik dari 3 variasi massa ragi tersebut menurut standar SNI (Standar Nasional Indonesia).

Variabel pada penelitian ini adalah memvariasi penambahan massa ragi terhadap kadar bioetanol dari kulit singkong dan kulit nanas dengan kombinasi beberapa perbandingan antara kulit singkong dan kulit nanas yaitu $100 \%$ kulit singkong dan $0 \%$ kulit nanas, $75 \%$ kulit singkong dan 25\% kulit nanas, 50\% kulit singkong dan 50\% kulit nanas, 25\% kulit singkong dan 75\% kulit nanas, $0 \%$ kulit singkong dan $100 \%$ kulit nanas

Kombinasi - kombinasi tersebut kemudian ditambahkan ragi sebanyak 11 gram, 13 gram dan 15 gram yang selanjutnya difermentasi. Proses fermentasi dilakukan selama 72 jam karena selama waktu tersebut dioetanol yang dihasilkan optimal, dan apabila waktu fermentasi dinaikkan maka bioetanol yang dihasilkan dalam proses fermentasi akan dikonversikan oleh Saccharomyces carevisae menjadi senyawa lain yang sah satunya adalah senyawa ester.

\subsection{Diagram alir penelitian}




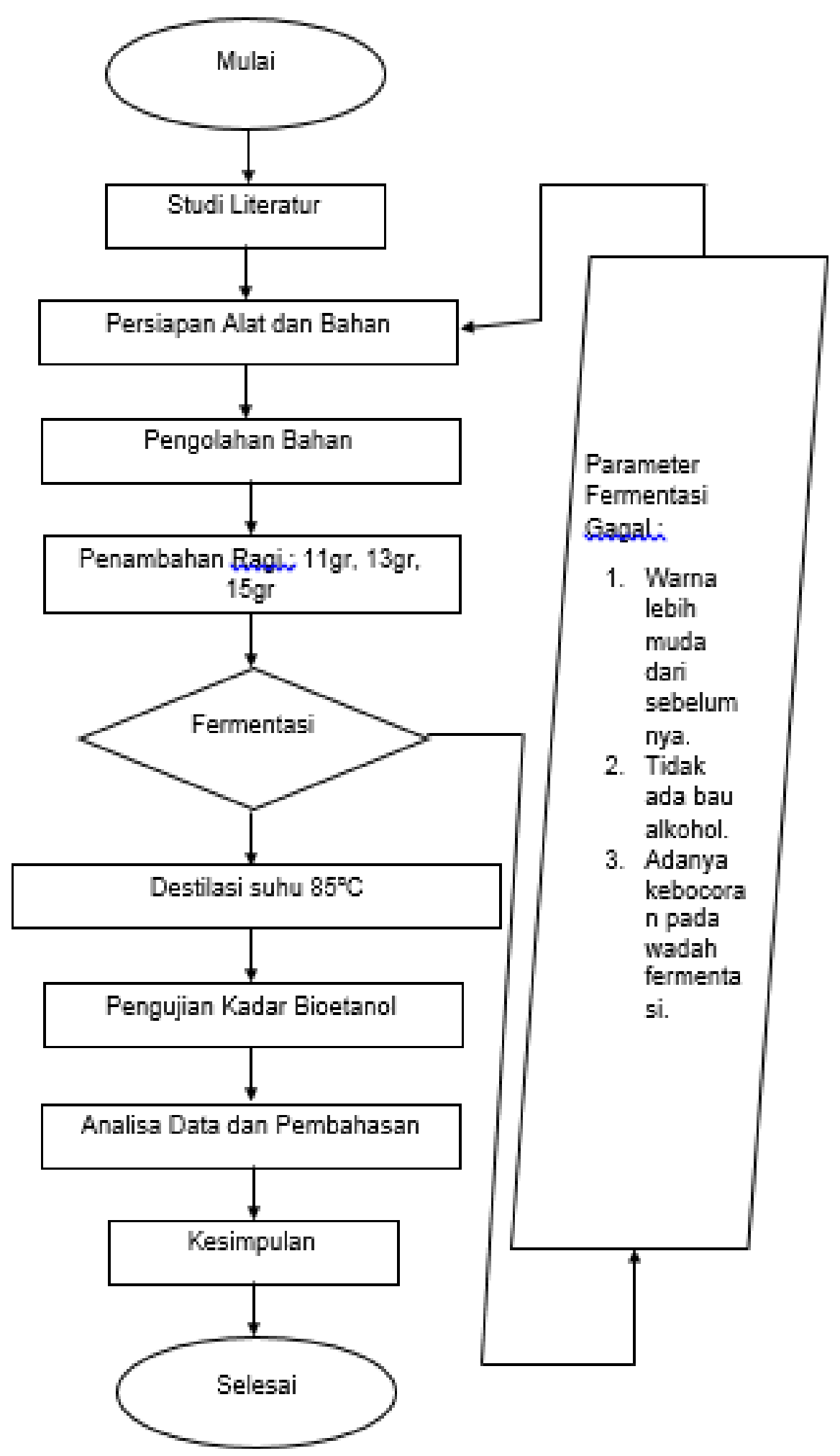

\section{HASIL DAN PEMBAHASAN}

Gambar 2. Diagram Penelitian

Dalam penelitian ini data yang diambil merupakan kadar etanol, volume etanol dan hasil randemen dari etanol, yang dikerjakan di Laboratorium Operasi Teknik Kimia Universitas Lambung Mangkurat dan Laboratorium Energi LPPM 
Institut Teknologi Sepuluh Nopember pada bulan Mei 2018 sampai dengan Juli 2018.

Tabel 1. Kadar Etanol Berdasarkan Variasi Massa Ragi

\begin{tabular}{|c|c|c|c|c|c|c|c|c|c|c|}
\hline \multirow[b]{2}{*}{ No. } & \multirow{2}{*}{$\begin{array}{l}\text { Jumlah } \\
\text { limbah } \\
\text { kulit } \\
\text { singkong } \\
\text { dan kulit } \\
\text { nanas } \\
\text { (gram) }\end{array}$} & \multirow{2}{*}{$\begin{array}{c}\text { Massa } \\
\text { kulit } \\
\text { singko } \\
\text { ng } \\
\text { (gram) }\end{array}$} & \multirow{2}{*}{$\begin{array}{l}\text { Massa } \\
\text { kulit } \\
\text { nanas } \\
\text { (gram) }\end{array}$} & \multirow{2}{*}{$\begin{array}{l}\text { Air } \\
(\mathrm{ml})\end{array}$} & \multicolumn{2}{|c|}{$\begin{array}{c}\text { Jumlah } \\
\text { Perbandingan }\end{array}$} & \multicolumn{2}{|c|}{$\begin{array}{l}\text { Persentase } \\
\text { etanol yang } \\
\text { terbentuk } \\
(\%)\end{array}$} & \multirow{2}{*}{$\begin{array}{l}\text { Volu } \\
\text { me } \\
\text { (ml) }\end{array}$} & \multirow{2}{*}{$\begin{array}{l}\text { Rand } \\
\text { emen }\end{array}$} \\
\hline & & & & & $\begin{array}{c}\text { Mas } \\
\text { sa } \\
\text { ragi }\end{array}$ & $\begin{array}{l}\text { Waktu } \\
\text { ferme } \\
\text { ntasi }\end{array}$ & $\begin{array}{l}\text { Pen } \\
\text { Refra } \\
\text { ktom } \\
\text { eter }\end{array}$ & $\begin{array}{l}\text { Gas } \\
\text { Chrom } \\
\text { atogra } \\
\text { phy }\end{array}$ & & \\
\hline \multirow{5}{*}{1} & \multirow{5}{*}{200} & 200 & 0 & \multirow{5}{*}{800} & \multirow{5}{*}{11} & \multirow{5}{*}{72} & 22 & - & 6 & 0,47 \\
\hline & & 150 & 50 & & & & 27 & - & 6 & 0,47 \\
\hline & & 100 & 100 & & & & 17 & - & 9 & 0,70 \\
\hline & & 50 & 150 & & & & 10 & - & 9 & 0,70 \\
\hline & & 0 & 200 & & & & 10 & - & 10 & 0,94 \\
\hline \multirow{5}{*}{2} & \multirow{5}{*}{200} & 200 & 0 & \multirow{5}{*}{800} & \multirow{5}{*}{13} & \multirow{5}{*}{72} & 37 & - & 7 & 0,55 \\
\hline & & 150 & 50 & & & & 38 & - & 6 & 0,47 \\
\hline & & 100 & 100 & & & & 27 & - & 6 & 0,47 \\
\hline & & 50 & 150 & & & & 25 & - & 8 & 0,62 \\
\hline & & 0 & 200 & & & & 16 & - & 9 & 0,70 \\
\hline \multirow{5}{*}{3} & \multirow{5}{*}{200} & 200 & 0 & \multirow{5}{*}{800} & \multirow{5}{*}{15} & \multirow{5}{*}{72} & 40 & 87,4 & 9 & 0,70 \\
\hline & & 150 & 50 & & & & 44 & 88,6 & 6 & 0,47 \\
\hline & & 100 & 100 & & & & 39 & 89,3 & 10 & 0,78 \\
\hline & & 50 & 150 & & & & 46 & 87,3 & 9 & 0,70 \\
\hline & & 0 & 200 & & & & 20 & 36,9 & 13 & 1,01 \\
\hline
\end{tabular}

\subsection{Perbandingan Hasil Uji Etanol Dengan Gas Chromatography dan Pen \\ Refractometer}

Nilai perbandingan kadar etanol pada kombinasi kulit singkong dan kulit nanas menggunakan pen refractometer dan gas chromatography dapat dilihat pada diagram perbandingan hasil uji etanol antara gas chromatography dengan pen refractometer berikut. 


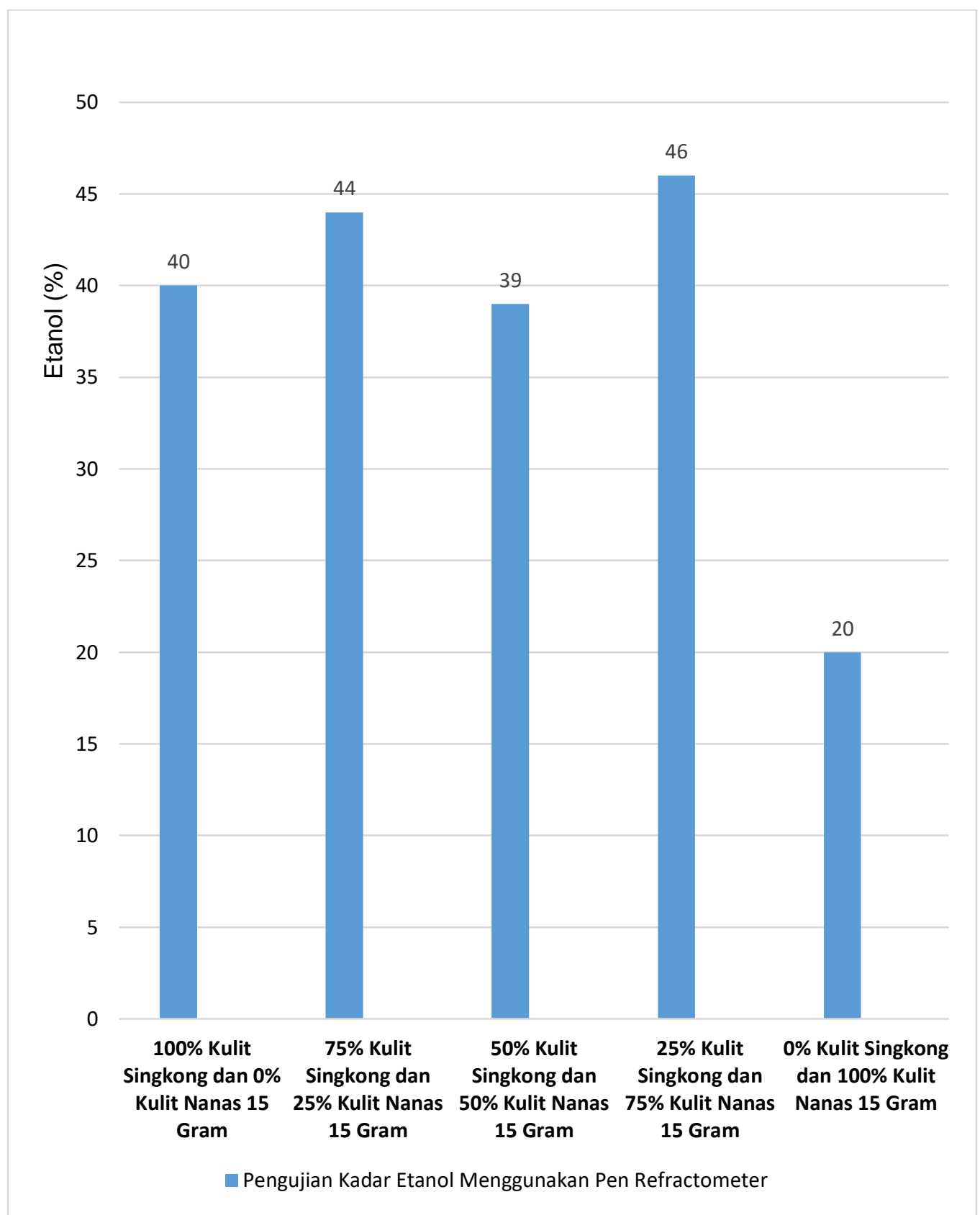

Gambar 3. Diagram Uji Etanol Dengan Pen Refractometer

Hasil kadar etanol menggunakan Pen Refractometer menunjukan kadar etanol yang dihasilkan pada kombinasi $100 \%$ kulit singkong dan $0 \%$ kulit nanas dengan variasi massa ragi 15 gram yaitu $40 \%$, kombinasi $75 \%$ kulit singkong dan $25 \%$ kulit nanas dengan variasi massa ragi 15 gram yaitu $44 \%$, kombinasi $50 \%$ kulit singkong dan 50\% kulit nanas dengan variasi massa ragi 15 gram yaitu $39 \%$, kombinasi $25 \%$ kulit singkong dan $75 \%$ kulit nanas dengan variasi massa ragi 15 gram yaitu $46 \%$, dan kombinasi $0 \%$ kulit singkong dan $100 \%$ kulit nanas dengan variasi massa ragi 15 gram yaitu $20 \%$. 


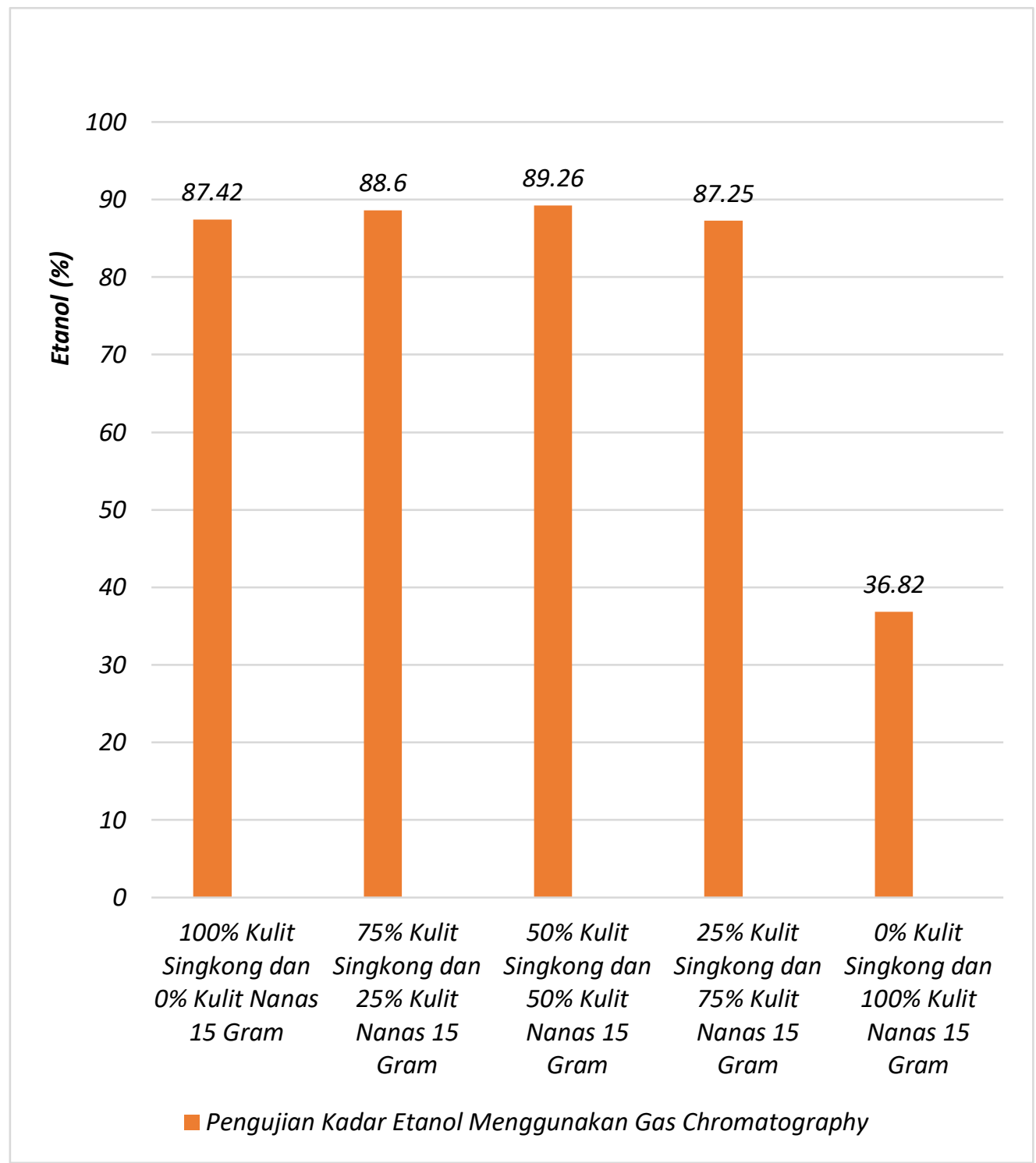

Gambar 4. Diagram Uji Etanol Dengan Gas Chromatography

Hasil kadar etanol menggunakan Gas Chromatography menunjukan kadar etanol yang dihasilkan pada kombinasi $100 \%$ kulit singkong dan $0 \%$ kulit nanas dengan variasi massa ragi 15 gram yaitu $87,42 \%$, kombinasi $75 \%$ kulit singkong dan $25 \%$ kulit nanas dengan variasi massa ragi 15 gram yaitu $88,6 \%$, kombinasi $50 \%$ kulit singkong dan $50 \%$ kulit nanas dengan variasi massa ragi 15 gram yaitu $89,26 \%$, kombinasi $25 \%$ kulit singkong dan $75 \%$ kulit nanas dengan variasi massa ragi 15 gram yaitu $87,25 \%$, dan kombinasi $0 \%$ kulit singkong dan $100 \%$ kulit nanas dengan variasi massa ragi 15 gram yaitu $36,82 \%$.

Dari grafik tersebut, perbandingan hasil uji kadar etanol diatas dapat diperhatikan bahwa data hasil pengujian kadar etanol menggunakan alat gas chromatography lebih tinggi, dibandingkan dengan data hasil pengujian kadar etanol dengan alat Pen Refractometer.

Sehingga pengujian kadar etanol dengan alat Gas Chromatography lebih diunggulkan karena data yang diperoleh lebih baik dibandingkan dengan data pengujian dengan Pen Refractometer. 


\subsection{Pertumbuhan Jamur pada proses fermentasi}

Pengaruh Variasi Massa Ragi 100\% Kulit Singkong dan 0\% Kulit Nanas Terhadap Kadar Etanol

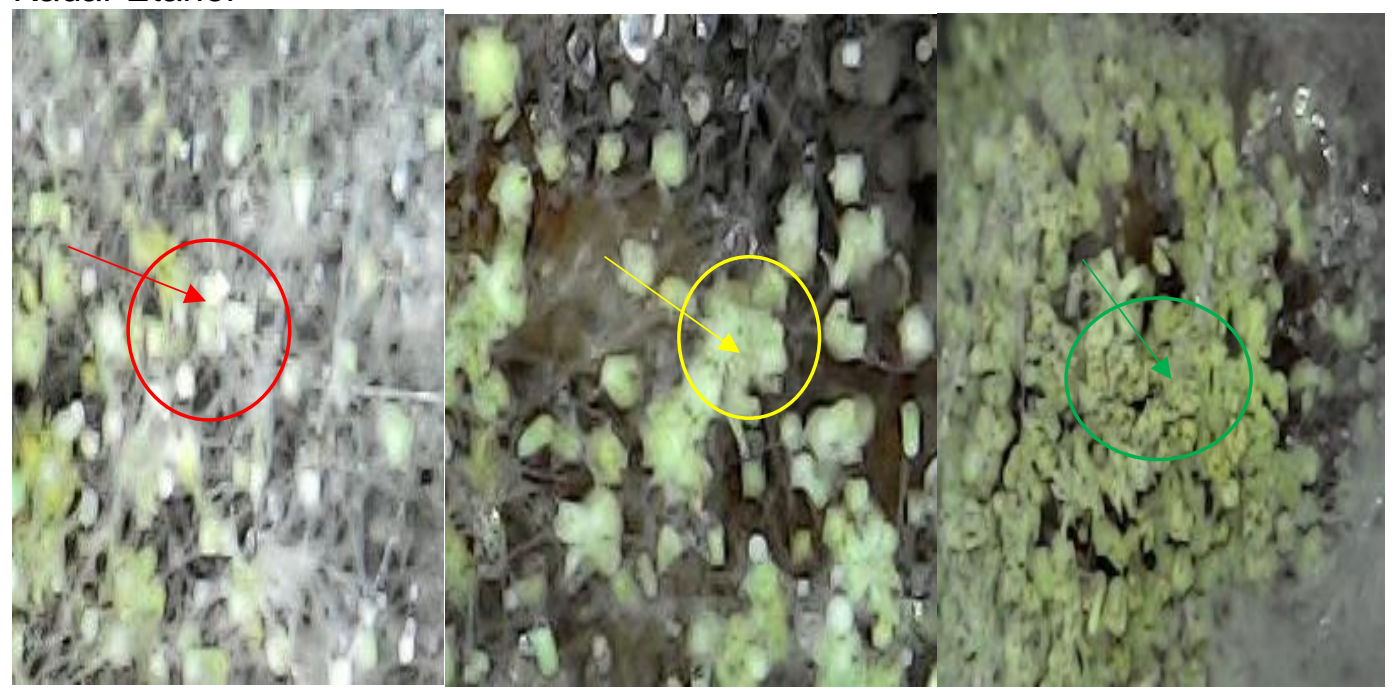

(a)

(b)

(c)

Gambar 6. Pertumbuhan jamur pada (a). Ragi 11gr (b). Ragi 13gr (c). Ragi 15gr

Dari gambar tersebut (a) pada kombinasi 100\% kulit singkong dan 0\% kulit nanas dengan penambahan massa ragi sebanyak $11 \mathrm{gram}$, terlihat jamur yang tumbuh tidak terlalu banyak, pada gambar (b) dengan penambahan massa ragi sebanyak 13 gram, pertumbuhan jamur mengalami peningkatan, dan pada (c) penambahan massa ragi sebanyak 15 gram, terlihat jumlah jamur semakin banyak. Hal ini disebabkan oleh banyaknya ragi (Saccharomyces Cerevisiae) yang ditambahkan sehingga mikroorganisme menguraikan glukosa menjadi etanol semakin banyak.

Pengaruh Variasi Massa Ragi 75\% Kulit Singkong dan 25\% Kulit Nanas Terhadap Kadar Etanol

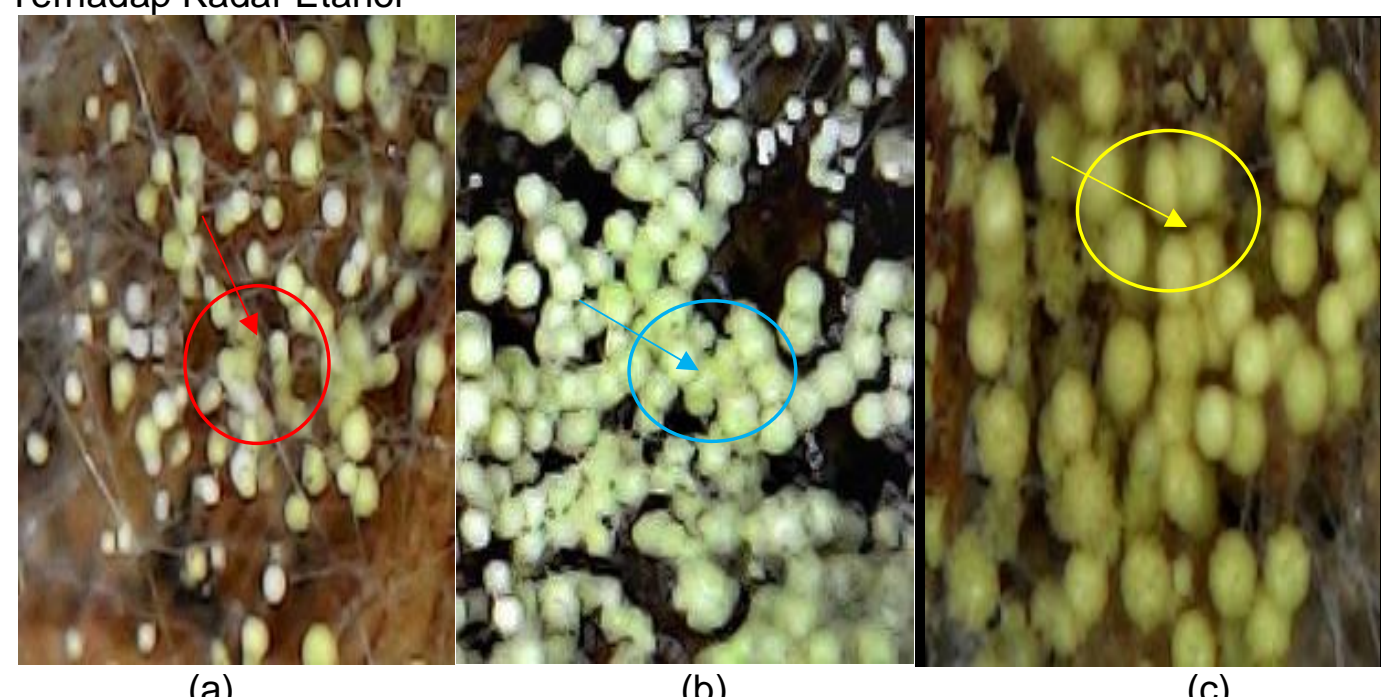

(a)

(b)

(c)

Gambar 7. Pertumbuhan jamur pada (a). Ragi 11gr (b). Ragi 13gr (c). Ragi 15gr

Dari gambar tersebut (a) pada kombinasi $75 \%$ kulit singkong dan $25 \%$ kulit nanas dengan penambahan massa ragi sebanyak 11 gram, terlihat jamur yang tumbuh tidak terlalu banyak, pada gambar (b) dengan penambahan massa ragi sebanyak 13 gram, pertumbuhan jamur mengalami peningkatan, dan pada (c) penambahan massa ragi sebanyak 15 gram, terlihat jumlah jamur semakin 
banyak. Hal ini disebabkan oleh banyaknya ragi (Saccharomyces Cerevisiae) yang ditambahkan sehingga mikroorganisme menguraikan glukosa menjadi etanol semakin banyak.

Pengaruh Variasi Massa Ragi 50\% Kulit Singkong dan 50\% Kulit Nanas Terhadap Kadar Etanol

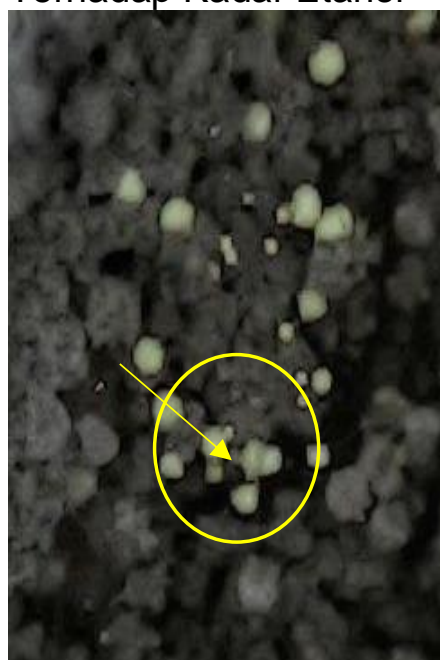

(a)

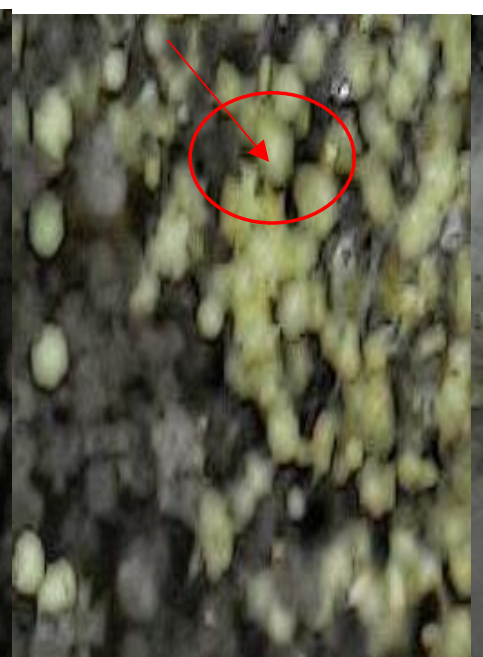

(b)

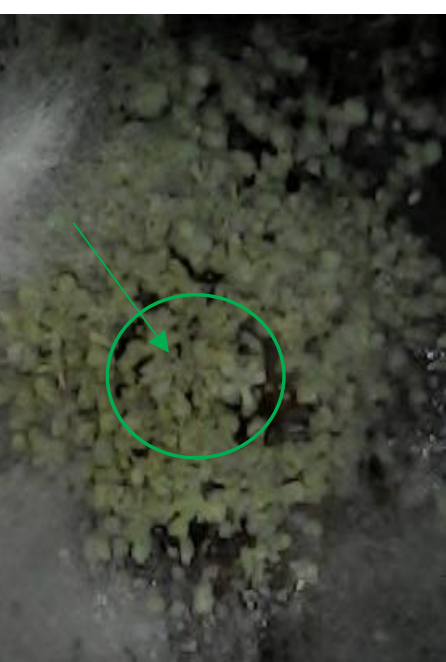

(c)

Gambar 8. Pertumbuhan jamur pada (a). Ragi 11gr (b). Ragi 13gr (c). Ragi 15gr

Dari gambar tersebut (a) pada kombinasi 50\% kulit singkong dan 50\% kulit nanas dengan penambahan massa ragi sebanyak $11 \mathrm{gram}$, terlihat jamur yang tumbuh tidak terlalu banyak, pada gambar (b) dengan penambahan massa ragi sebanyak 13 gram, pertumbuhan jamur mengalami peningkatan, dan pada (c) penambahan massa ragi sebanyak 15 gram, terlihat jumlah jamur semakin banyak. Hal ini disebabkan oleh banyaknya ragi (Saccharomyces Cerevisiae) yang ditambahkan sehingga mikroorganisme menguraikan glukosa menjadi etanol semakin banyak.

Pengaruh Variasi Massa Ragi 25\% Kulit Singkong dan 75\% Kulit Nanas Terhadap Kadar Etanol.

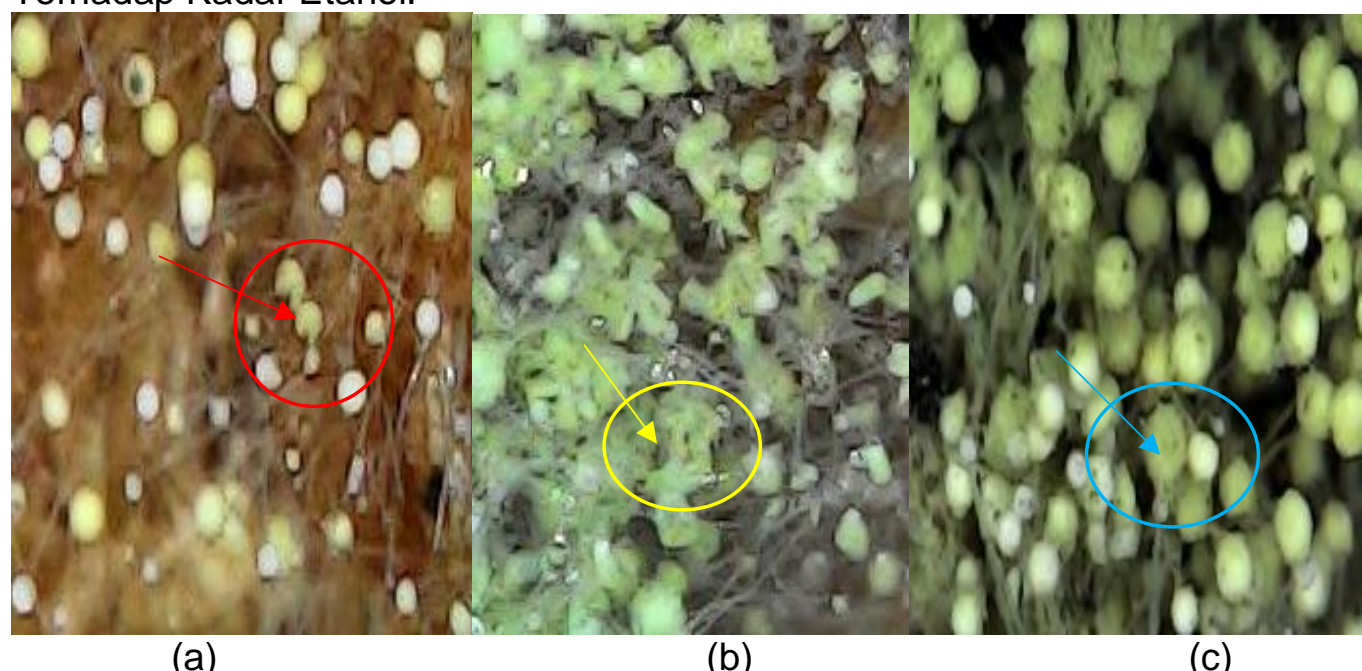

Gambar 9. Pertumbuhan jamur pada (a). Ragi 11gr (b). Ragi 13gr (c). Ragi 15gr

Dari gambar tersebut (a) pada kombinasi $25 \%$ kulit singkong dan $75 \%$ kulit nanas dengan penambahan massa ragi sebanyak $11 \mathrm{gram}$, terlihat jamur yang tumbuh tidak terlalu banyak, pada gambar (b) dengan penambahan massa ragi sebanyak 13 gram, pertumbuhan jamur mengalami peningkatan, dan pada (c) penambahan massa ragi sebanyak 15 gram, terlihat jumlah jamur semakin 
banyak. Hal ini disebabkan oleh banyaknya ragi (Saccharomyces Cerevisiae) yang ditambahkan sehingga mikroorganisme menguraikan glukosa menjadi etanol semakin banyak.

Pengaruh Variasi Massa Ragi 0\% Kulit Singkong dan 100\% Kulit Nanas Terhadap Kadar Etanol

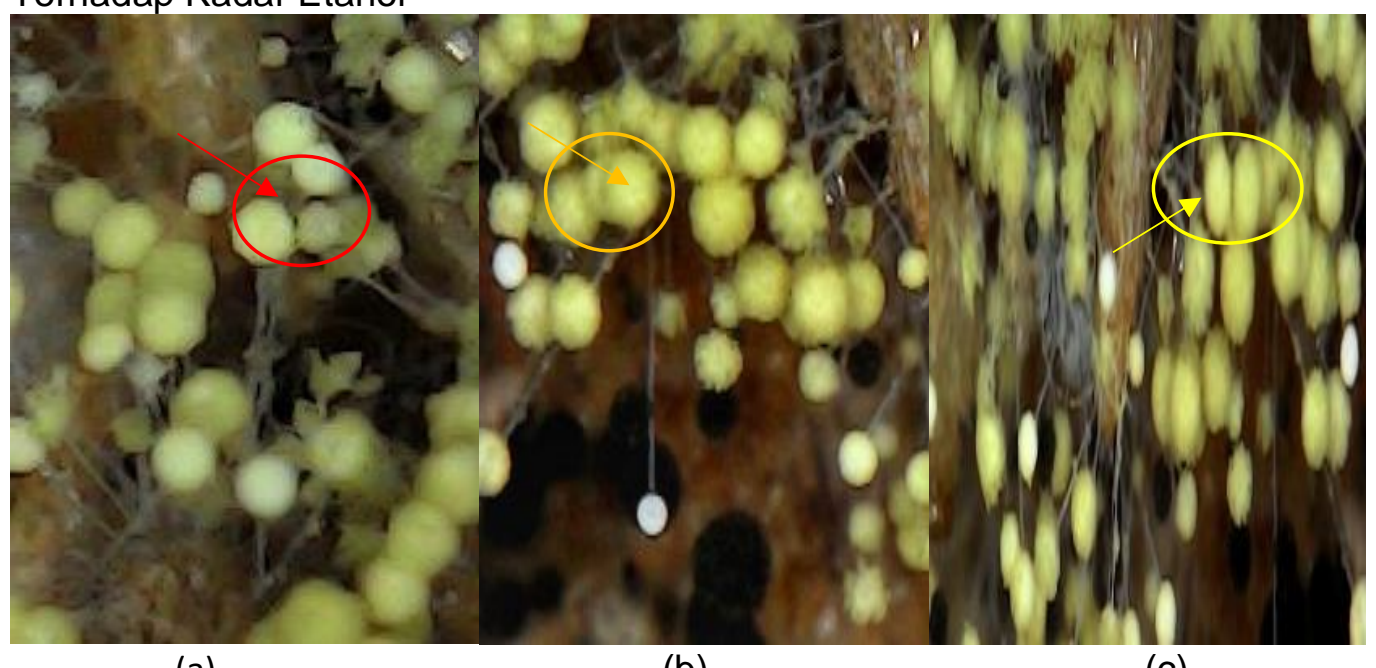

(a)

(b)

(c)

Gambar 10. Pertumbuhan jamur pada (a). Ragi 11gr (b). Ragi 13gr (c). Ragi 15gr

Dari gambar tersebut (a) pada kombinasi 0\% kulit singkong dan 100\% kulit nanas dengan penambahan massa ragi sebanyak 11 gram, terlihat jamur yang tumbuh tidak terlalu banyak, pada gambar (b) dengan penambahan massa ragi sebanyak 13 gram, pertumbuhan jamur mengalami peningkatan, dan pada (c) penambahan massa ragi sebanyak 15 gram, terlihat jumlah jamur semakin banyak. Hal ini disebabkan oleh banyaknya ragi (Saccharomyces Cerevisiae) yang ditambahkan sehingga mikroorganisme mengurai glukosa menjadi etanol semakin banyak.

Menurut standar nasional Indonesia dan mengacu pada Standar Nasional Indonesia Bioetanol, standar nasional Indonesia untuk bioetanol yaitu 94,00\%. Untuk mengetahui memenuhi dan tidaknya kadar etanol menutur standard SNI dari penelitian ini dapat di liaht pada tabel berikut.

Tabel 2. Kualitas Kadar Etanol Menurut Tabel Standar Standar Nasional Indonesia.

\begin{tabular}{|c|c|c|c|c|c|c|c|c|}
\hline No. & \begin{tabular}{c} 
Campuran \\
\cline { 2 - 8 } \\
$\begin{array}{c}\text { Kassa } \\
\text { Singkong } \\
\text { (gram) }\end{array}$
\end{tabular} & $\begin{array}{c}\text { Massa } \\
\text { Kulit } \\
\text { Nanas } \\
(\mathrm{gram})\end{array}$ & $\begin{array}{c}\text { Variasi } \\
\text { Ragi } \\
(\mathrm{gram})\end{array}$ & $\begin{array}{c}\text { Waktu } \\
\text { Fermentasi } \\
(\text { jam })\end{array}$ & $\begin{array}{c}\text { Sampel } \\
\text { Uji } \\
\text { Etanol } \\
(\mathrm{ml})\end{array}$ & $\begin{array}{c}\text { Presentase } \\
\text { Kadar } \\
\text { Etanol } \\
(\%)\end{array}$ & $\begin{array}{c}\text { Standar } \\
\text { SNI }\end{array}$ & $\begin{array}{c}\text { Lulus } \\
\text { dan } \\
\text { Tidak } \\
\text { Lulus }\end{array}$ \\
\hline 1 & 200 & 0 & 15 & 72 & 8 & 87.4 & 94.0 & $\begin{array}{c}\text { Tidak } \\
\text { Lulus }\end{array}$ \\
\hline 2 & 150 & 50 & 15 & 72 & 6 & 88.6 & 94.0 & $\begin{array}{c}\text { Tidak } \\
\text { Lulus }\end{array}$ \\
\hline 3 & 100 & 100 & 15 & 72 & 10 & 89.3 & 94.0 & $\begin{array}{c}\text { Tidak } \\
\text { Lulus }\end{array}$ \\
\hline 4 & 50 & 150 & 15 & 72 & 9 & 87.3 & 94.0 & $\begin{array}{c}\text { Tidak } \\
\text { Lulus }\end{array}$ \\
\hline 5 & 0 & 200 & 15 & 72 & 13 & 36.8 & 94.0 & $\begin{array}{c}\text { Tidak } \\
\text { Lulus }\end{array}$ \\
\hline
\end{tabular}


Dapat dilihat bahwa dari hasil penelitian ini kadar etanol tertinggi didapat dari kombinasi 50\% kulit singkong dan 50\% kulit nanas dengan variasi ragi 15 gram yang telah dilakukan pengujian dengan menggunakan alat Gas Chromatograpy untuk mengetahui kemurnian kadar etanol sebenarnya. Kadar etanol yang dihasilkan sebesar $89,3 \%$.

Sehingga dapat disimpulkan bahwa kadar etanol dari kombinasi kulit singkong dan kulit nanas ini, tidak masuk dalam kategori standar nasional Indonesia (SNI).

\section{v. KESIMPULAN}

1. Dari kombinasi $100 \%$ kulit singkong dan $0 \%$ kulit nanas dengan variasi massa ragi 15 gram menghasilkan kadar etanol sebanyak 87,4\%. Kombinasi $75 \%$ kulit singkong dan $25 \%$ kulit nanas dengan variasi massa ragi 15 gram menghasilkan kadar etanol sebanyak $88,6 \%$. Kombinasi $50 \%$ kulit singkong dan $50 \%$ kulit nanas dengan variasi massa ragi 15 gram menghasilkan kadar etanol sebanyak $89,3 \%$. Kombinasi $25 \%$ kulit singkong dan $75 \%$ kulit nanas dengan variasi massa ragi 15 gram menghasilkan kadar etanol sebanyak $87,3 \%$. Kombinasi $0 \%$ kulit singkong dan $100 \%$ kulit nanas dengan variasi massa ragi 15 gram menghasilkan kadar etanol sebanyak $36,8 \%$.

2. Dari hasil penelitian ini kombinasi yang paling optimal pertumbuhan jamurnya berada pada kombinasi 50\% kulit singkong dan 50\% kulit nanas dengan massa ragi 15 gram dan waktu fermentasi 72 jam yang menghasilkan kadar etanol sebanyak $89,3 \%$.

3. Dari penelitian ini kadar etanol tertinggi didapat dari kombinasi $50 \%$ kulit sungkong dan $50 \%$ kulit nanas dengan variasi ragi 15 gram, etanol yang dihasilkan yaitu $89,3 \%$. Sehingga dapat disimpulkan bahwa kadar etanol dari kombinasi kulit singkong dan kulit nanas ini, tidak masuk dalam kategori standar nasional Indonesia (SNI).

\section{DAFTAR PUSTAKA}

Amien. 2006. Pentingnya Fermentasi Bir Kokoa. http:///www.alumni_ipd.or.id. Diakses tanggal 11 Desember 2018

Ani Rahmawati. 2010. Pemanfaatan Limbah Kulit Ubi Kayu (Manihot Utilissima Pohl.) dan Kulit Nanas (Ananas Comosus L.) Pada Produksi Bioetanol Menggunakan Aspergillus Niger. Fakultas MIPA Univesitas Sebelas Maret. Surakarta.

Astawan. M dan M. W. Astawan. 1991. Teknologi Pengolahan Pangan Nabati Tepat Guna. Bogor : Akademika Pressiado.

Astawan, M dan W. Mita. 1991. Teknologi Pengolahan Nabati Tepat Guna. CV.Akademika Pressindo. Bogor. Hal 61

Badan Standardisasi Nasional. 2008. SNI 7290:2008. Bioetanol Terdenaturasi untuk Gasohol. Jakarta.

Dony Fahmi, dkk. 2014. Pemurnian Etanol Hasil Fermentasi Kulit Nanas (Ananas comosus L. Merr) Dengan Menggunakan Distilasi Vakum. Fakultas Teknologi Pertanian, Universitas Brawijaya. Jawa Timur.

Khairani, Emma. 2014. Pemanfaatan Kulit Nanas Jadi Bioetanol. Medan.

Nurdyastuti, I. 2007. Teknologi Proses Produksi Bio-Ethanol. Makalah prospek pengembangan Bio-fuel Sebagai Subtitusi Bahan Bakar Minyak : 75-83.

Prastowo. Bambang. 2007. Potensi Sektor Pertanian Sebagai Penghasil dan Pengguna Energi Terbarukan. Bogor.

Rukmana, R. 1997. Ubi Kayu Budidaya Paskapanen. Jakarta : Kanisius.

Sally Mandari, dkk. 2013. Pembuatan Bioetanol dari Kulit Nanas (ananas comusus 1) Menggunakan Enzim Selulase dan Yeast Saccharomyces Cerevisiae dengan Proses Simultaneous Sacharification dan Fermentasion (SSF). Program Studi Teknik Kimia, Fakultas Teknik, Universitas Riau. Riau. 
Tjokroadikoesoemo, P. S. 1986. HFS dari industry Ubi Kayu dan Lainnya. Gramedia. Jakarta. $229 \mathrm{hlm}$.

Winarno, F. G. 1995. Enzin Pangan. Jakarta : Gramedia.

Zulaikah, Siti. 2002. Ilmu Bahan Makanan I. Surakarta. Universitas Muhammadiyah Surakarta. 